\title{
Study on changing patterns of reproductive behaviours due to maternal features and place of residence in Poland during 1995-2014
}

\author{
Agnieszka Genowska1, Krystyna Szafraniec ${ }^{2}$, Maciej Polak² , Andrzej Szpak², Irena Walecka ${ }^{4}$, \\ Jakub Owoc ${ }^{5}$ \\ ${ }^{1}$ Department of Public Health, Medical University of Bialystok, Poland \\ ${ }^{2}$ Department of Epidemiology and Population Studies, Jagiellonian University Medical College, Krakow, Poland \\ ${ }^{3}$ Department of Epidemiology, Demography and Biostatistics, Institute of Rural Health, Lublin, Poland \\ ${ }^{4}$ Clinic of Dermatology, Central Clinical Hospital, Ministry of Internal Affairs, Warsaw \\ ${ }^{5}$ College of Public Health, Zielona Góra, Poland
}

Genowska A, Szafraniec K, Polak M, Szpak A, Walecka I, Owoc J. Study on changing patterns of reproductive behaviours due to maternal features and place of residence in Poland during 1995-2014. Ann Agric Environ Med. 2018; 25(1): 137-144. doi: 10.26444/aaem/75544

\section{Abstract}

Introduction. The sharp decline in the total fertility rate in Poland coincided with broader socio-economic changes, which resulted in its reduction to the lowest level observed among the countries of Central and Eastern Europe.

Objective. The aim of the study was to investigate and evaluate the changing patterns of reproductive behaviour in rural and urban areas, depending on the demographic and socio-economic features in Poland.

Materials and method. Information about live births in Poland in the years 1995-2014 were obtained from the Central Statistical Office. Registered cases of live births in rural and urban areas were analyzed considering the maternal features (age, marital status, main source of income). To evaluate the changes in fertility and comparisons between rural and urban areas, Joinpoint Regresssion was used.

Results. In 1995-2014, a shift in the age of highest fertility from 20-24 years to 25-29 years was observed. This occurred at the same time as a reduction in the fertility rate per 1,000 women aged 15-29 years, more pronounced in rural areas (95.8 to 60.0) than in urban areas (63.4 to 51.5), while in women aged 30-49 years, a faster increase in fertility was observed in urban areas (16.4 to 32.0) than in rural areas (27.5-29.2). Fertility trends between rural and urban areas differed significantly. A significant increase in live births for employed mothers was shown mainly in 2005-2009; later, the growth rate in rural areas was slower and in urban areas the growth trend stopped.

Conclusion. The postponement of births and reduction of fertility in women aged 15-29 requires active measures aimed at creating favourable conditions for achieving economic independence for the younger generation, as well as combining work with raising children, especially in rural areas.

\section{Key words}

fertility, inequality in procreation, maternal age, socio-economic status, marital status, rural-urban, Poland

\section{Abbreviations}

APC - annual percentage change; AAPC - average annual percentage change; CSO - Central Statistical Office; TFR - total fertility rate

\section{INTRODUCTION}

The decrease in fertility rates below the generation's replacement level is the result of changes in establishment and functioning of the families that started in the 1960s in Western and Northern Europe. These changes are referred as the second demographic transition, associated with the destabilization of families manifested by the decreasing importance of marriage, increase in informal partnerships, and dissemination of divorce $[1,2]$. The reason was the increasing level of education and women's economic activity, and the possibility of the use of contraceptives. Not only has the upsurge of independence and self-realization among individuals played a role in the decisions regarding the delay of starting a family and deferment of births, but also in

Addres for correspondence: Agnieszka Genowska, Department of Public Health Medical University of Bialystok, Szpitalna 37, 15-295 Bialystok, Poland

E-mail: agnieszka.genowska@umb.edu.pl

Received: 8 December 2016; accepted: 22 March 2017; first published on May 2017 voluntary childlessness $[3,4,5]$. In the countries of Central and Eastern Europe and South America, these changes occurred until 1980. Reduction in the total fertility rates (TFR) to below 2 in Poland, Slovakia, and Lithuania, was reported in 1992, and at the beginning of 2000-2001 the ratio decreased below 1.3. This is defined as the lowest reproductive level and has led to unfavourable changes in the population structure and population aging $[6,7]$.

In Poland, the period of sudden decline in TFR coincided with the broader changes in socio-economic problems related to the establishment of democracy, and the transition to a market economy [8]. The reorganization of the State was associated with the withdrawal of social functions (reduction in the number of public childcare facilities and access to affordable housing), and increased individual responsibility for the financial situation. Furthermore, the lack of employment guarantees from the State, connected to the high demands of the labour market, led to a rapid increase in unemployment $[9,10]$. Improvement in the situation 
occurred when the Polish accession to the European Union resulted in the intensification of economic migration and a rapid drop in unemployment. In the period 2004-2009, the increase of TFR from 1.23 to 1.40 was observed; but after 2009 , the fertility rate decreased again, probably due to the economic crisis $[11,12]$. The socio-economic changes were associated with the rise in the priorities to education and improved access to education at the tertiary level, which contributed to the career development of women, as well as to postponing of the first child. This was typically 25.8 years in 1990 that changed to 29.5 years in 2014 [11].

Poland, compared to other countries in Central and Eastern Europe, in 2014, was still characterized by the lowest TFR (1.32) and was ranked in the last five European Union countries, along with Portugal (1.23), Greece (1.30), Cyprus (1.31), and Spain (1.32). In these countries, the low fertility rate coincided with low levels of employment. Whereas, the highest TFR is currently recorded in the countries of Western and Northern Europe - France (2.01), Ireland (1.94), Sweden (1.81), and the United Kingdom (1.81). Surprisingly, late age marriages and the high level of divorces are commonly observed in these countries, but the high fertility rate may be the result of family policies and favourable solutions that are aimed at combining work with raising children $[13,14]$.

Reproductive behaviour may be related to many factors, which include marital status [15], age [11], socio-economic status of parents [16], housing conditions [17], unemployment [18], access to institutional care for children [14], and the level of urbanization [19]. Rural and urban areas are characterized by significant differences in education, occupation, income level, marriages, number of children in the household, and the problems occurring in the immediate vicinity, i.e., population density, air and water quality $[20,21]$. These features can differentiate the reproductive behaviour between rural and urban areas, which is attractive for the analysis. However, evidences from the research on this subject is scarce $[22,23,24,25,26,27]$.

\section{OBJECTIVE}

The aim of the study was to investigate and evaluate the changing patterns of reproductive behaviour in rural and urban areas, depending on the demographic and socioeconomic features in Poland.

\section{MATERIALS AND METHOD}

The analysis was based on information about the fertility of the female population in Poland in 1995-2014. Information for the analysis was obtained from the Central Statistical Office (CSO). The study included cases of registered live births in rural and urban areas, considering the demographic characteristics and socio-economic features concerning mothers. The number of live births by maternal age (both by total age range, 15-49 years, and in age groups, 15-19, 20-24, 25-29, 30-34, 35-39, 40-44, 45-49), marital status (legitimate live births), and the main source of mothers' income (employed, dependent on other persons, non-earned sources), were analysed.

The analysis used fertility rates expressed as the number of live births per number of women of childbearing age
(15-49) converted into 1,000, and the partial coefficients expressing the number of live births among women and the number of these women in the same age groups. Births to mothers under 15 years of age were included in the group 15-19 years, and births from mothers aged 50 and above were included in the age group 45-49. Also analyzed was the TFR indicating the average number of children that would be born to a woman during her entire reproductive period (15-49 years), assuming that in particular phases of this period she would give birth at the same intensity as that observed among women in the audited year.

For each year, the percentage was calculated of live births in marriages (number of births among women who were married / live births in a given year, total $\left.{ }^{\star} 100\right)$. In the same way, live births in given years were calculated according to the income of the mother (number of live births among women for whom income was from employment / all live births in a given year ${ }^{*} 100$ ), and the percentage of live births derived from mothers who remained dependent on other persons, and with non-earned sources of income.

The distribution of fertility rate, TFR and the percentage of live births for the years 1995-2014, were described by specifying the means with $95 \%$ confidence intervals, while comparisons of analyzed variables between the women living in rural and urban areas were made using the Student's t test for paired samples. To examine the trend for fertility rates and trends in percentages of live births in marriages in the years 1995-2014, Joinpoint Regression was used, which allows the best fit pieces of the continuous log-linear model. The model assumed assessment of parameters using Weighted Least Squares and random error consistent with the Poisson distribution. This enabled the changes and the size of the population in the years of the observation data to be taken into account. The results of the estimated linear trends were presented as partial annual percentage changes (APC) with 95\% confidence intervals. Trends of marital live births were shown by the average annual percentage change (AAPC) with $95 \%$ confidence intervals. The differences during the examined trends between rural and urban areas were also examined using the Wald test.

Territorial distribution of fertility rates in terms of place of residence (rural, urban) are shown on the map of Polish counties (Powiat).

Statistical analysis was performed using the statistical packages $\mathrm{IBM}^{\circledast} \mathrm{SPSS}^{\circledast}$ Statistics for Windows, Version 22.0 (IBM Corp., Armonk, NY, USA) and Joinpoint Regression Program 4.0.4-2013. All statistical hypotheses were verified at the significance level of 0.05 .

\section{RESULTS}

In 1995-2014, there were 7,750,389 live births in Poland, of which 3,363,258 occurred in rural areas children (43.4\%). The number of live births from marriages in rural and urban areas amounted to 2,927,035 (86.8\%) and 3,530,166 (80.5\%), respectively. In the structure of the main source of mothers' income in the analyzed period, employment dominated, which in rural areas accounted for a much lower percentage than in urban areas (45.6\% vs. $62.5 \%$ ), while in rural areas many more mothers than in urban areas remained dependent on other people (27.9\% vs. $21.0 \%)$. A similar proportion of 
Table 1. Descriptive statistics of fertility rate and percentage of legitimate live births, 1995-2014

\begin{tabular}{|c|c|c|c|c|c|c|}
\hline \multirow{3}{*}{$\begin{array}{l}\text { Mater- } \\
\text { nal } \\
\text { age }\end{array}$} & \multicolumn{3}{|c|}{ Fertility rate* } & \multicolumn{3}{|c|}{$\begin{array}{c}\text { Percentage of legitimate live } \\
\text { births }\end{array}$} \\
\hline & Rural areas & Urban areas & & Rural areas & Urban areas & \\
\hline & $\begin{array}{c}\text { Mean } \\
(95 \% \mathrm{Cl})\end{array}$ & $\begin{array}{l}\text { Mean } \\
(95 \% \mathrm{Cl})\end{array}$ & $\mathrm{p}$ & $\begin{array}{l}\text { Mean } \\
(95 \% \mathrm{Cl})\end{array}$ & $\begin{array}{l}\text { Mean } \\
(95 \% \mathrm{Cl})\end{array}$ & $\mathrm{p}$ \\
\hline $15-19$ & $\begin{array}{c}18.5 \\
(16.7,20.2)\end{array}$ & $\begin{array}{c}14.7 \\
(13.8,15.6)\end{array}$ & $<0.001$ & - & - & \\
\hline $20-24$ & $\begin{array}{c}92.3 \\
(78.8,105.9)\end{array}$ & $\begin{array}{c}56.8 \\
(49.5,64.1)\end{array}$ & $<0.001$ & $\begin{array}{c}81.8 \\
(77.4,86.1)\end{array}$ & $\begin{array}{c}70.0 \\
(63.9,76.2)\end{array}$ & $<0.001$ \\
\hline $25-29$ & $\begin{array}{c}106.6 \\
(102.9,110.3)\end{array}$ & $\begin{array}{c}84.6 \\
(82.9,86.3)\end{array}$ & $<0.001$ & $\begin{array}{c}91.9 \\
(90.3,93.5)\end{array}$ & $\begin{array}{c}87.0 \\
(84.8,89.2)\end{array}$ & $<0.001$ \\
\hline $30-34$ & $\begin{array}{c}64.0 \\
(61.1,67.0)\end{array}$ & $\begin{array}{c}59.0 \\
(53.7,64.4)\end{array}$ & 0.03 & $\begin{array}{c}92.6 \\
(91.4,93.9)\end{array}$ & $\begin{array}{c}87.7 \\
(86.2,89.2)\end{array}$ & $<0.001$ \\
\hline $35-39$ & $\begin{array}{c}27.5 \\
(26.4,28.6)\end{array}$ & $\begin{array}{c}23.7 \\
(21.3,26.2)\end{array}$ & $<0.001$ & $\begin{array}{c}91.1 \\
(89.6,92.5)\end{array}$ & $\begin{array}{c}83.4 \\
(81.7,85.1)\end{array}$ & $<0.001$ \\
\hline $40-44$ & $\begin{array}{c}6.6 \\
(6.3,6.9)\end{array}$ & $\begin{array}{c}4.8 \\
(4.4,5.2)\end{array}$ & $<0.001$ & $\begin{array}{c}89.4 \\
(88.1,90.7)\end{array}$ & $\begin{array}{c}79.1 \\
(77.1,81.0)\end{array}$ & $<0.001$ \\
\hline $45-49$ & $\begin{array}{c}0.32 \\
(0.29,0.34)\end{array}$ & $\begin{array}{c}0.2 \\
(0.18,0.22)\end{array}$ & $<0.001$ & $\begin{array}{c}89.3 \\
(87.4,91.2)\end{array}$ & $\begin{array}{c}79.2 \\
(76.5,81.9)\end{array}$ & $<0.001$ \\
\hline $15-49$ & $\begin{array}{c}46.6 \\
(44.1,49.1)\end{array}$ & $\begin{array}{c}35.6 \\
(33.8,37.5)\end{array}$ & $<0.001$ & $\begin{array}{c}86.8 \\
(84.6,89.0)\end{array}$ & $\begin{array}{c}80.5 \\
(78.4,82.7)\end{array}$ & $<0.001$ \\
\hline
\end{tabular}

* fertility rate per 1,000 women in this age group; $\mathrm{Cl}$ - Confidence Interval

$p-t$ Student test for paired samples

women in rural and urban areas had income from noncommercial sources (12.1\% vs. $11.9 \%)$.

A significantly higher average fertility rate per 1,000 women aged 15-49 in the period 1995-2014 was observed in rural areas (46.6) than in urban areas (35.6). The highest values for average fertility rate of fractions occurred in the age group 25-29 years (rural areas: 106.6, urban areas: 84.6), the lowest intensity of fertility was observed in women in the oldest age group 45-49 years (rural areas: 0.32 , urban areas: 0.20 ). Decidedly more children came from marriages; the average percentage of live births among married women aged 15-49 was significantly higher in rural areas than in urban areas $(86.8 \%$ vs. $80.5 \%)$. The differences between rural areas and urban areas in terms of fertility rates and the percentage of live births in marriages were significant in each age group (Tab. 1). In the reporting period, TFR was significantly higher in rural areas (1.57, 95\% CI: 1.47-1.67), compared to urban areas (1.21, 95\% CI: $1.18-1.24)$.

In the last two decades in rural and urban areas, there have been significant changes in the patterns of reproductive behaviours involving postponing births (Fig. 1). In rural areas in 1995, the highest fertility rate, with a value of 144.9 / 1,000 women, was in the age group 20-24 years. In 2002, in the rural areas there was a shift in the highest fertility (103.8) for the age group 25-29 years, and in 2014 this pattern was maintained, but the value of the ratio decreased to 99.7. For women in urban areas, the rates were lower, and changes in patterns of reproductive behaviours were slightly different, which was associated with an earlier movement in the highest fertility to the age of 25-29 years. In 1995, in urban areas the highest fertility rates were observed in women aged 20-24 and 25-29 (90.7 and 91.3, respectively). A year later, the highest fertility had shifted to the age of 25-29 (90.2). After 20 years observation, in 2014, in women aged 20-24, the coefficient had decreased significantly (41.2), the highest fertility in urban areas occurred in the age group 25-29 (83.2). In women aged 30-34, relatively high fertility rates and values in this group were observed after two decades, and there was an increase in fertility rates in rural and urban areas. In women over 35, fertility rates increased in urban areas between 1995 and 2014, while in rural areas they decreased.

Results from the analysis indicate a high fluctuation in trends for fertility rates per 1,000 women of childbearing age in both rural and urban areas. In the initial period 1995-2003/2004, a significant decrease in the fertility rate of women aged 15-29 in rural areas was observed (95.8-64.1)

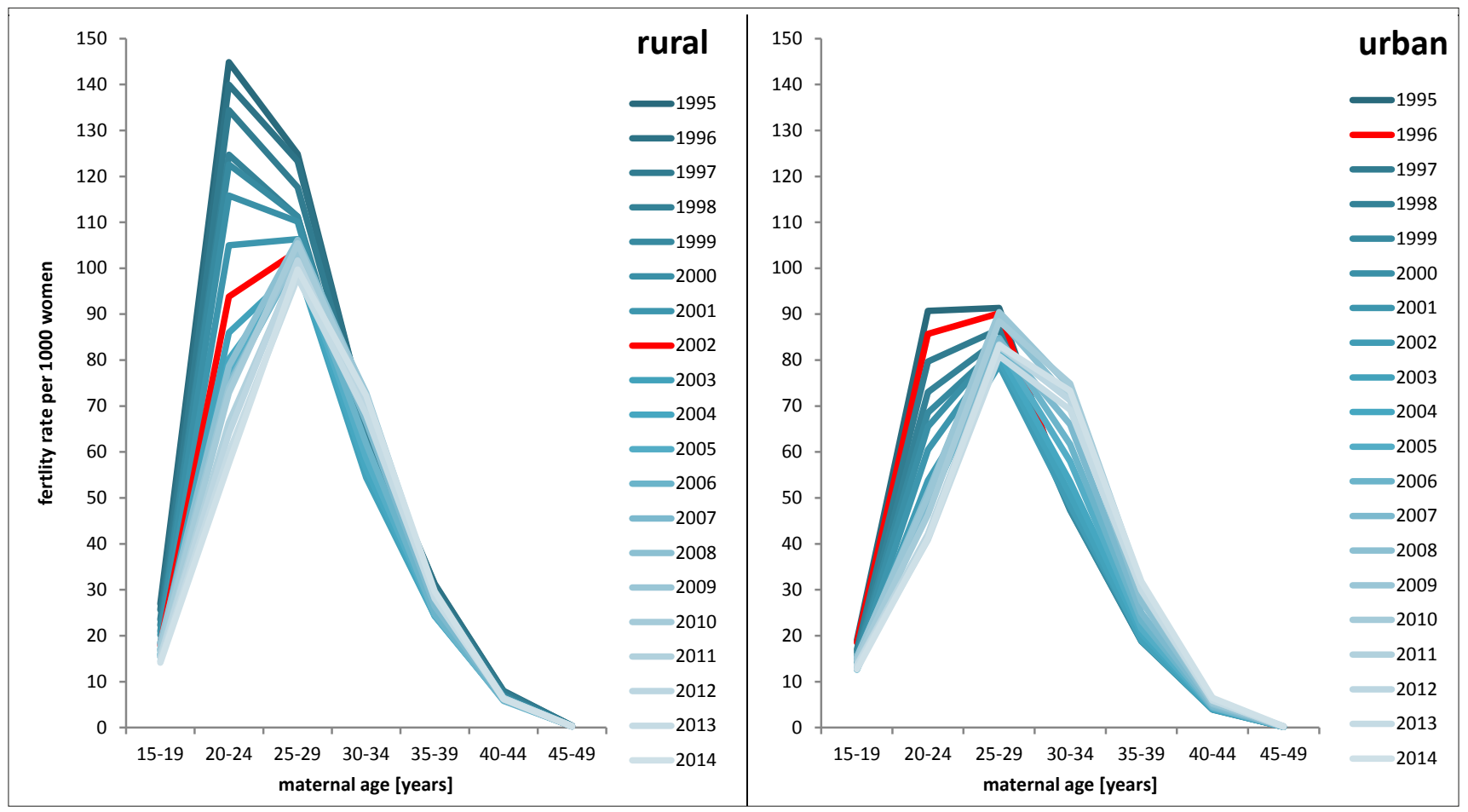

Figure 1. Fertility rate per 1,000 women relative to maternal age and place of residence, 1995-2014 
and urban areas (63.4-48.9). The next period, until 2009, brought a change of direction to the trend in urban areas (up to 56.9); in rural areas there were no significant changes. In later years, up to 2014, in urban areas the direction of the trend changed again (decreased to 51.5), also in rural areas the ratio significantly decreased (from 66.5 to 60.0 ). In women aged 30-49 in rural areas in 1995-2003, there was a significant downward trend (27.5-20.9), while in urban areas until 2002 the ratio fluctuated from 16.4 to 14.7. In the period 2003-2009 in rural areas, the trend changed direction to become positive (rising to 28.3), between 2002-2009 in urban areas a significant increase in the fertility rate (15.7-30.6) was observed. In subsequent years, in rural and urban areas the trend was stable, but from 2008 the fertility rate for women aged 30-49 in urban areas was higher (28.5-32.0) than in rural areas (27.7-29.2). The overall fertility rate of women aged 15-49 in the early years to 2002-2004, significantly decreased in rural areas (58.6-41.6) and urban areas (35.130.6 ), then at the turn of the year 2008-2009, there was a change in direction of the trend in rural and urban areas (an increase to 46.9 and 42.2). Another change in the direction of the trend in the period 2008/2009-2014 was associated with a significant decrease in fertility rates in rural areas (to 42.4) and urban areas (to 39.3). Significant differences in the slope of fertility trends between rural and urban areas are presented in Figure 2 and Table 2.

The maps show the territorial diversity of reproductive behaviours in 2014 in rural and urban areas in the Polish counties (Fig. 3). In rural areas, fertility rate per 1,000 women aged 15-49 ranged from 29.9-56.6 (average 42.3). The lowest fertility rates in rural areas, amounting to 34.4 , were reported in eastern Poland, in the districts of the Provinces of Podlaskie (Siematycki), Świętokrzyskie (Kazimierski), Lubelskie (Krasnystawski, Zamojski), Podkarpackie (Niżański, Stalowowolski), as well as in the counties located in the southern part of the country, in Opolskie (Kluczborski, Opolski), Śląskie (Będziński) and Dolnośląskie (Jeleniogórski). At the same time, the highest fertility rates in rural areas, as high as over 50.0, did not form a uniform pattern and were scattered in the counties of the Pomorskie Province (Kartuski, Wejherowski, Bytowski, Lęborski, Chojnicki), Małopolskie (Limanowski, Nowosądecki), Wielkopolskie (Nowotomyski, Krotoszyński, Średzki, Śremski), Mazowieckie (Garwoliński), Warmińsko-Mazurskie (Nowomiejski) and Kujawsko-Pomorskie (Brodnicki). In urban areas, fertility rates ranged from 23.5-50.8 (average 38.4). The lowest value - 29.8 - was observed in the counties of eastern Poland, located in Świętokrzyskie Province (Opatowski, Pińczowski, Kazimierski), Podkarpackie (Tarnobrzeski, Leski, Bieszczadzki) and Podlaskie (Moniecki, Łomżyński), as well as in western Poland, in Wielkopolskie Province (Leszczyński, Kaliski), Zachodniopomorskie (Kołobrzeski) and Dolnośląskie (Złotoryjski). The highest fertility in urban areas (over 50.0) was seen in counties in Mazowieckie Province (Garwoliński, Ostrołęcki) and Dolnośląskie (Milicki). Among the cities with county status, the lowest fertility was observed

Table 2. Trends in fertility rate (per 1,000 women) by age groups and place of residence, 1995-2014

\begin{tabular}{|c|c|c|c|c|c|c|c|c|}
\hline \multirow{2}{*}{$\begin{array}{l}\text { Maternal age / } \\
\text { place of residence }\end{array}$} & & \multicolumn{2}{|c|}{ Trend 1 ( 0 joinpoint $)$} & \multicolumn{2}{|c|}{ Trend 2 ( 1 joinpoint) } & \multicolumn{2}{|c|}{ Trend 3 ( 2 joinpoint) } & \multirow[b]{2}{*}{$\mathrm{p}^{* *}$} \\
\hline & & Years & $\begin{array}{c}\text { APC } \\
(95 \% \mathrm{Cl})\end{array}$ & Years & $\begin{array}{c}\mathrm{APC} \\
(95 \% \mathrm{Cl})\end{array}$ & Years & $\begin{array}{c}\text { APC } \\
(95 \% \mathrm{Cl})\end{array}$ & \\
\hline 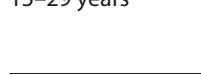 & urban & $1995-2003$ & $\begin{array}{c}-3.4^{*} \\
(-3.9,-2.8)\end{array}$ & 2003-2009 & $\begin{array}{c}2.8^{*} \\
(1.5,4.0)\end{array}$ & 2009-2014 & $\begin{array}{c}-2.2^{*} \\
(-3.6,-0.9)\end{array}$ & $<0.001$ \\
\hline 30-49 years & urban & 1995-2002 & $\begin{array}{c}-0.8 \\
(-2.0,0.4)\end{array}$ & 2002-2009 & $\begin{array}{c}10.9^{*} \\
(9.4,12.5)\end{array}$ & 2009-2014 & $\begin{array}{c}0.1 \\
(-1.5,1.6) \\
\end{array}$ & $<0.001$ \\
\hline \multirow{2}{*}{$15-49$ years } & rural & 1995-2004 & $\begin{array}{c}-4.2^{*} \\
(-4.5,-3.8)\end{array}$ & 2004-2008 & $\begin{array}{c}3.6^{*} \\
(1.7,5.6)\end{array}$ & 2008-2014 & $\begin{array}{c}-1.7^{*} \\
(-2.4,-1.1)\end{array}$ & \multirow{2}{*}{$<0.001$} \\
\hline & urban & $1995-2002$ & $\begin{array}{c}-2.1^{*} \\
(-2.9,-1.3)\end{array}$ & 2002-2009 & $\begin{array}{c}4.8^{*} \\
(3.7,5.8)\end{array}$ & 2009-2014 & $\begin{array}{c}-1.6^{*} \\
(-2.9,-0.3)\end{array}$ & \\
\hline
\end{tabular}

APC - Annual Percent Change; $\mathrm{Cl}$ - Confidence interval

$(*)$ - Statistically significant trend at $p<0.05$

$(* *)$ - Wald test for significance of differences trends in 1995-2014

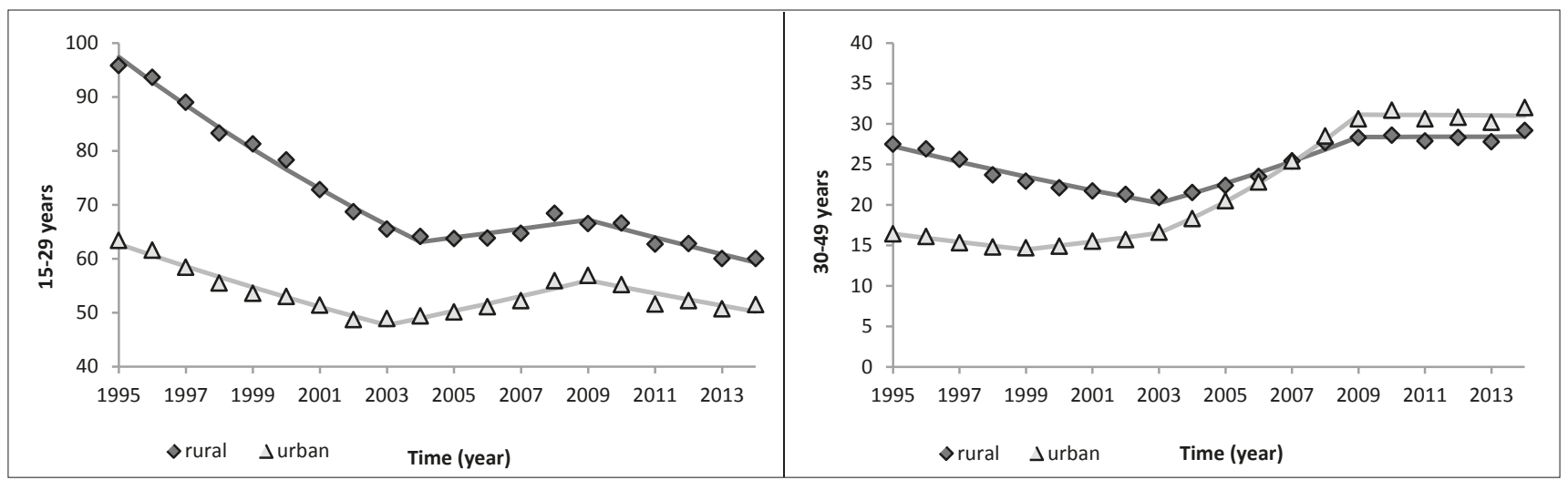

Figure 2. Trends in fertility rate (per 1,000 women) by age groups and place of residence in Poland, 1995-2014 

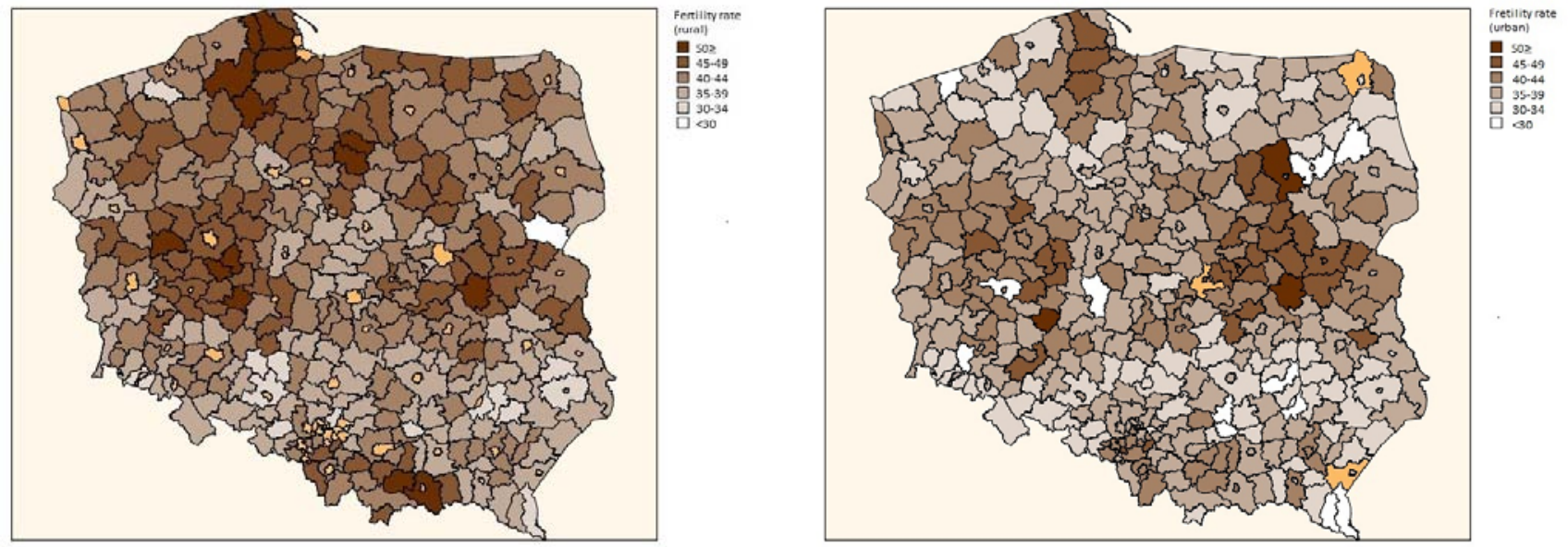

Figure 3. Territorial distribution of fertility rate per 1,000 women aged 15-49 years, according to place of residence in Polish counties, 2014

* yellow indicates counties inhabited by urban people (left) and counties inhabited by rural people (right).

in Tarnobrzeg (27.7), Świnoujscie (31.1), Chełm (33.0), and the highest fertility values were observed in Żory (47.4), Siedlce (47.1) and Warsaw (46.1).

In both rural and urban areas, variable dynamics in TFR trends were observed. In rural areas in 1995-2004, TFR values significantly decreased in the subsequent period to 2008 , when there was a stabilization of the trend, and then until 2014 it decreased again. In urban areas, by 2003 TFR had strongly decreased, in the period 2003-2009, the trend changed direction to become significantly positive, and after 2009 there was another change into a negative trend. The difference in trends between rural and urban areas throughout the analyzed period was statistically significant. From 1995, the value of TFR observed in rural areas (2.02) did not guarantee a simple replacement of generations. In 2002, for the first time the rate surpassed the level of low fertility (1.5). In urban areas, the TFR was significantly lower than in rural areas, and for the years 1995-2014 it ranged below the lowest-low fertility (1.3), with slight variations in 2008-2009. In 2014, the TFR in rural and urban areas amounted to 1.39 and 1.22 (Tab. 3).

In the period 1995-2014, a negative linear trend in the percentage of live births from married women was observed in both rural areas (AAPC $=-0.88,95 \%$ CI: $-0.98,-0.78$ ) and urban areas (AAPC $=-0.94,95 \%$ CI: $-1.08,-0.80$ ). The difference in trends between rural and urban areas was statistically significant $(\mathrm{p}<0.01)$.

In 1995-2014, large changes in the percentage of live births were seen, depending on the main source of the mother's income and place of residence (Tab. 4). For females in

Table 3. Trends in total fertility rate in terms of place of residence, 1995-2014

\begin{tabular}{|c|c|c|c|c|c|c|c|c|}
\hline \multirow[b]{2}{*}{ Place of residence } & & \multicolumn{2}{|c|}{ Trend 1 ( 0 joinpoint) } & \multicolumn{2}{|c|}{ Trend 2 (1 joinpoint) } & \multicolumn{2}{|c|}{ Trend 3 ( 2 joinpoint) } & \multirow[b]{2}{*}{$\mathrm{p}^{* *}$} \\
\hline & & Years & $\begin{array}{c}\text { APC } \\
(95 \% \mathrm{Cl})\end{array}$ & Years & $\begin{array}{c}\text { APC } \\
(95 \% \mathrm{Cl})\end{array}$ & Years & $\begin{array}{c}\text { APC } \\
(95 \% \mathrm{Cl})\end{array}$ & \\
\hline $\begin{array}{l}\text { Total } \\
\text { fertility } \\
\text { rate }\end{array}$ & urban & $1995-2003$ & $\begin{array}{c}-1.9^{*} \\
(-2.6,-1.2)\end{array}$ & $2003-2009$ & $\begin{array}{c}2.9^{*} \\
(1.4,4.5)\end{array}$ & 2009-2014 & $\begin{array}{c}-2.0^{*} \\
(-3.5,-0.6)\end{array}$ & $<0.001$ \\
\hline
\end{tabular}

APC - Annual Percent Change; $\mathrm{Cl}$ - Confidence interval; $\left(^{*}\right)$ - Statistically significant trend at $\mathrm{p}<0.05 ;\left(^{* *}\right)$ - Wald test for significance of differences trends in $1995-2014$

Table 4. Trends in percentage of live births by mothers' main source of income and place of residence, 1995-2014

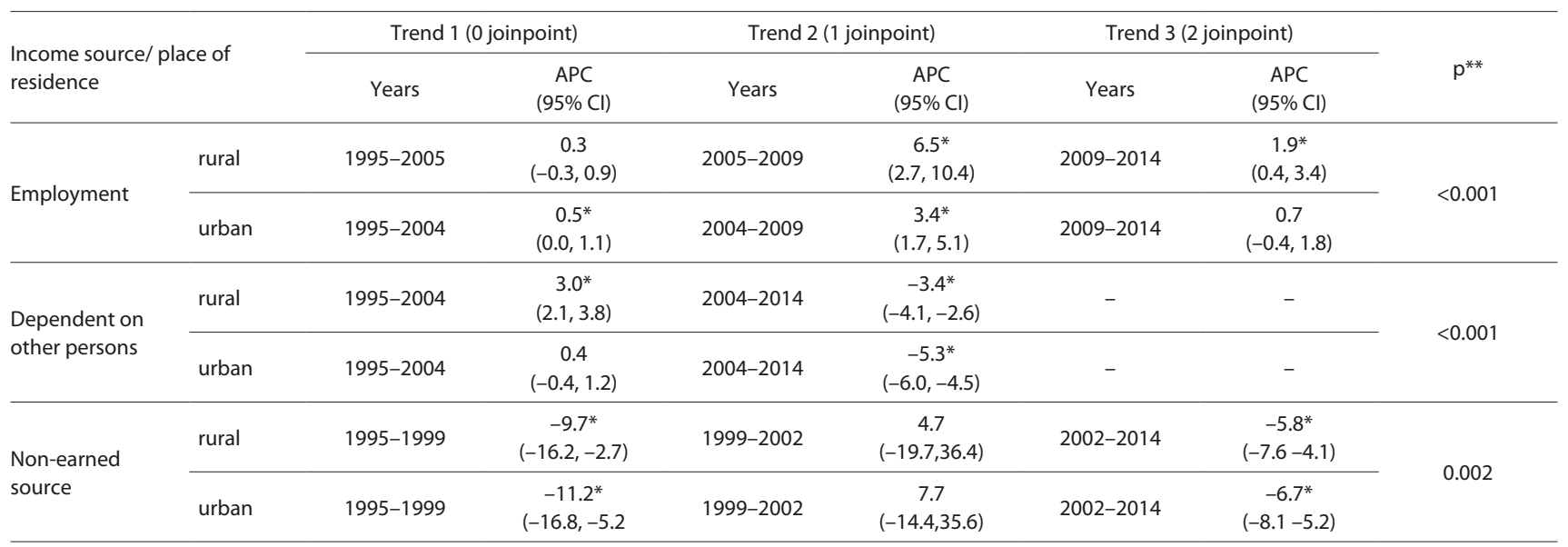

APC - Annual Percent Change; $\mathrm{Cl}$ - Confidence interval; $\left(^{*}\right)$ - Statistically significant trend at $\mathrm{p}<0.05 ;\left(^{* *}\right)$ - Wald test for significance of differences trends in $1995-2014$ 
employment, the percentage of live births in the initial period 1995-2004/2005 in rural areas remained stable, and in urban areas demonstrated a significant growth. In 2004/2005-2009, irrespective of the place of residence, an increasing trend was observed. Thereafter, in rural areas the growth continued, but slowed down; in urban areas there was no change. In women dependent on other persons, the initial trend in the percentage of live births by 2004 in rural areas was increasing, while in urban areas there were no significant changes; in the later years in rural areas, the trend was reversed and up to the end of the period decreased; also, in urban areas the observed trends decreased. In rural and urban areas in women with non-earned incomes, the percentage of live births decreased significantly until 1999. For several years, until 2002, the trend was stable, and the later reported decreasing trend lasted until 2014. Trends in the percentage of live births for all analyzed sources of mothers' income differed between rural and urban areas (Tab. 4).

\section{DISCUSSION}

Main findings. In the last two decades in the rural and urban areas there was a change in the reproductive behaviour pattern involving the postponement of childbirths until an older age. Among women aged 15-29 in rural and urban areas fertility rate trend has changed over the years - initially decreased, then increased in the period of 2003/2005-2009 and decreased again, but despite significant decrease in the fertility rate it was still higher in the rural areas. In women aged 30-49, initially a decrease in fertility was observed, mainly in rural areas, and in the period of 2002/2003-2009, rapid growth was observed in rural and urban areas. In later years, there has been a stabilization of fertility rates; but since 2008 , the infertility rate has been higher in urban areas. The trend of live births among employed mothers in rural areas significantly increased in the period 2005-2014; similar changes were observed in 1995-2009 in the urban areas, and the trend remained stable after 2009. During two decades, a negative linear trend in the percentage of live births from married women was observed in both rural and urban areas.

Limitations and strengths. The results of this study should be interpreted in the light of some limitations. Unfortunately, the Central Statistics Office (CSO) system does not have more detailed information about unmarried mothers, divorced mothers living in different partnerships (cohabitation and living apart together), or about single parents. In the category of the information on main source of income of mothers dependent on others persons, it does not consider the relationship or family ties with the other person. These information gaps make a more detailed analysis of (in)stability of families in Poland and assessment of the directions of its development, impossible. This study was largely descriptive and does not apply to contextual factors of reproductive behaviour in rural and urban areas. The problems associated with the high degree of aggregation of the information collected in routine national systems were also noted by other researchers [28]. Despite these limitations, this study on inequality in reproductive behaviour, with the information already available from public statistics, broadens knowledge about the fertility of women in the rural and urban areas of Poland. However, this is the first study to present the differences in fertility between rural and urban areas of Poland which includes data for 20 years (1995-2014), using Weighted Least Squares considering the changes in population size over time. This method made it possible not only to estimate the long-term trends in fertility, including polygonal chains and identification of the calendar year in which there has been a significant change in trend, but also differences in the dynamics of trends between urban and rural areas. This study can be used to monitor changes in the level of fertility, as well as for determining the directions of family policy.

The advantage of the study is the use of national data, which allows the performing of analyses with high statistical power. The study used complete data about live births based on information derived from statistical reports on births. Considering the rural-urban criterion, the analysis helps to increase the knowledge of demographic processes in the rural population of Poland, which is currently the largest among the European Union countries with a large share of people employed in agriculture [29]. The strength of the study is that the significant statistical data are also presented in maps showing geographic diversity of fertility rates in the rural and urban areas, which can help to identify the areas requiring action aimed in increasing the fertility rates.

Comparison with other studies. The results obtained in this study are similar to those observed in studies conducted in other countries [15, 18, 30, 31, 32, 33], despite the disparate methods used to estimate them. Analysis of changes in the patterns of reproductive behaviour during the period of 19952014 indicated a similar shift in the age of highest fertility, from $20-24$ to 25-29 years, both in rural and urban areas; but in rural areas this process proceeded with several years of delay compare to urban areas. The changes in reproductive behaviour were also characterized by the decreasing fertility among women aged 15-29, which could be due to the decrease in the number of people born in individual years reaching the age of marriage [11]. Demographic forecast prepared by the CSO proposes that by 2020 the proportion of the population of potential mothers aged 15-24 is expected to reduce in rural (from $28.0 \%$ to $23.4 \%$ ) and urban (from $22.8 \%$ to $18.9 \%$ ) areas. In the older age group of $25-34$ years, the decline will continue until 2035 (rural: $31.1 \%-26.3 \%$, urban: $34.6 \%-26.5 \%$ ) [34]. This forecast is another worrying signal that requires intensive actionsin family policies of the state. These trends indicate that the TFR for the next generation is still not guaranteed.

A significant decrease in the fertility rate of women aged 15-29 was observed between 1995-2014 at a faster pace for rural areas (95.8-60.0, i.e. $37 \%)$, compared to urban areas (63.4 -51.5, i.e. $19 \%)$. This result can be explained by profound changes in the labour market of limiting agricultural activity into increased activity in trade and services [35]. The most severe effects of these transformations were associated with the mass liquidation of State-owned farms, and the decline in labour demand among inhabitants of rural areas. This led to permanent deterioration of living conditions through an increase in poverty, which is not conducive to childbearing decisions. As a consequence, it also changed the practice of inheriting farms that have been a parental strategy of resource allocation affecting reproduction. Changes of inheritance concerned, in particular, the men characterized by a higher education, which allowed the departure of agricultural labour 
to other professions with better prospectives for earning [36, 37]. The transformation of the employment structure is also engaged in urban areas, but the decrease in employment in the industrial sector in favour of employment in the service sector [35] could affect the weaker pace of decline in fertility compared to rural areas.

Despite a significant decline in the fertility rate of women aged 15-29 in rural and urban areas, the infertility rate is still higher in rural areas which may indicate the strength of inequality in procreation among this age group. Favourable conditions for procreation in rural areas can be attained by following a more traditional approach to the family, such as stronger preference for the establishment of large families and women caring for others, better housing conditions (mainly large houses and relatively low maintenance costs), easy access to housing, as well as space for leisure (gardens, parks) $[22,38]$. However, in urban areas, lower levels of fertility can be related not only to the economic difficulties in buying an apartment and a competitive labour market that requires flexibility of young women, but also to the lifestyle-oriented childlessness [19]. Poland is a country with significant unstable employment conditions, which especially affects the young people entering the labour market. The limitation of job opportunities in rural areas is due to the mismatch between their qualifications and the needs of the labour market, and lower quality of education [39]. In this context, the significant decrease in fertility of women aged 15-29 requires active measures aimed at creating favourable conditions for achieving the economic independence of the young generation, to increase the availability of affordable housing, and combining the work with child rearing, especially in rural areas.

The pattern of behaviour of women in the reproductive age of 30-49 was characterized by the faster growth of fertility rate in urban areas (16.4-32.0), compared to rural areas (27.5-29.2), while from 2009 the rate remained stable and its value was higher in urban areas. This result may indicate the better conditions for women living in urban areas to have children after 30 years of age, which could involve the possibility of obtaining higher incomes, better access to the labour market, and child care services, compared to rural areas $[20,38]$.The described transformations in the pattern of procreative behaviour are the sign of postponing births, and it may be associated with the increase in the average age of getting married, as well as aspirations to obtain an education and start a career, which also involve the subsequent establishment of a family [40]. Whereas these changes in the increased age of mothers (and fathers) is associated with a better preparation for the role of a parent, as well as greater opportunities to provide appropriate conditions for the upbringing of children resulting from the professional stability. On the other hand, excessive deferring of procreation plans can bring voluntary childlessness or childlessness forced by biological factors $[41,42,43]$.

The source of a mother's income seems to be a key factor in the rise of fertility rate, which may be the cause of changes in the live birth trends of employed mothers. In rural areas, the growing trend of live births among working mothers was observed during 2005-2014, and this period coincided with the change in direction of the trend from positive to negative in mothers dependent on other persons, as well as a decrease in the trend of births among mothers living from non-earned sources. In the urban areas, the positive trend of live births of employed mothers lasted until 2009, and during this time the percentage of live births from mothers who were dependent on other persons and who lived on non-earned source of income was reduced. The period after 2009, which was characterized by a slower rise in wages [44], in urban areas, brought stabilization in the trend of live births of employed mothers, while in rural areas an uptrend began. This result may be due to the deeper impact of adverse changes in the macroeconomic situation on fertility decisions in urban areas. The level of female employment in rural areas is lower, but the financial difficulties may be mitigated by the support from the family (usually extended). The differences between rural and urban areas, with the benefit being higher for rural areas, can also be due to the higher cost of living that exists in urban areas, which is mainly associated with expensive food and high rents for apartments [45]. Although the upward trend of live births has stopped in the urban areas since 2009, the level of fertility rate among people aged 30-49 was higher compared to the rural areas. Exceeding levels of fertility in the urban areas concerning the rural areas? was observed in 2007, which showed the indications of a strong drive for decisions about procreation. This change may be associated with an increase in the number of nurseries in urban areas [39]. Unfortunately, a weaker development of institutional care for children and exclusion of mothers from the labour market is observed in rural areas, which results in a lower rate of fertility among this age group in rural areas.

An apparent problem in the rural and urban areas is a constant decrease in the percentage of live births in marriages, which may be associated with the prevalence of cohabitation $[14,15]$. This observation can lead to the belief that in future years the reduction of births in marriages will continue. Live marriage births were more prevalent in rural areas where there were stronger ties between generations and stronger social control in the immediate vicinity. Also, the religiosity associated with the conservative attitude toward extramarital births is characteristic of the rural population. In urban areas, greater anonymity can contribute to the alternative of traditional family life choices of partnership formations [25]. Single mothers, in contrast to married mothers, are often in a lower socio-economic status, which does not guarantee the proper development of their children [46].

Regardless of the place of residence, a worrying result of the relatively high fertility rate of mothers of young age, under 19 years, was found. Possible causes for this phenomenon are the lower age of sexual initiation, as well as the lack of sex education in the school system [46]. The problem is stressed by the fact that juvenile mothers who gave birth to an overall number of 11,130 children (rural areas: 5097, urban areas 6033) in 2014, due to the social, economic and emotional dependence of their mothers, are exposed to worse development conditions. This situation requires taking active measures to support the acquisition of education that could increase the better chances in life of these women and their children.

\section{CONCLUSIONS}

Changes in the patterns of reproductive behaviour associated with postponement of the decision on childbearing in the rural areas appeared to be delayed, compared to urban areas, which confirms the cultural differences and socio-economic 
situation of the rural population. A significant decline in the fertility of women aged 15-29 requires active measures aimed at creating conditions favourable for achieving the economic independence of the young generation, as well as combining work with child rearing, especially in rural areas. Among women aged 30-49, inhibition of fertility growth after 2009 which was released together with the rate of live births of employed women, there is a need support women who are in a disadvantaged situation. The differences in the level of fertility of women between the rural and urban areas, after the age of 30 that occurred in 2007, suggest the need to develop institutional care for children in rural areas. The heterogeneity of the reproductive behaviour in the rural and urban areas should be considered in development programmes aimed at improving the living conditions of less educated women at childbearing age, residing in areas with a lower level of economic development.

\section{REFERENCES}

1. Lestahaeghe R. A Century of demographic and cultural change in Western Europe: an exploration of underlying dimensions. Popul Develop Rev. 1983; 9(3): 411-434.

2. Van de Kaa DJ. Europe's second demographic transition. Popul Bull. 1987; 42(1): 1-57.

3. Engelhardt H, Kögel T, Prskawetz A. Fertility and women's employment reconsidered: a macro-level time-series analysis for developed countries, 1960-2000. Popul Stud (Camb).2004; 58(1): 109-120.

4. Snopkowski K, Kaplan H. A Synthetic biosocial model of fertility transition: testing the relative contribution of embodied capital theory, changing cultural norms, and women's labor force participation. Am J Phys Anthropol.2014; 154(3): 322-333.

5. Okólski M. Wyzwania demograficzne Europy i Polski. Stud Socjol. 2010; 199(4): 37-78.

6. Frejka T, Sobotka T. Fertility in Europe: Diverse, delayed and below replacement. Demogr Research. 2008; 19(3): 15-46.

7. Kohler H, Billari F, Ortega J. Low fertility in Europe: causes, implications and policy options. In: Harris F. (Ed.). The baby bust who will do the work? Who will pay the taxes? Lanham: Rowman \& Littlefield Publishers 2006.

8. Frejka T. Determinants of family formation and childbearing during the societal transition in Central and Eastern Europe. Demogr Research. 2008; 19(7): 139-170.

9. Kotowska I, Jóźwiak J, Matysiak A, Baranowska A. Poland: Fertility Decline as a response to profound societal and labor market changes? Demogr Research.2008;19(22): 795-854.

10. Modena F, Rondinelli C. Economic insecurity and fertility intentions: the case of Italy. Review Income Wealth. 2014; 60(Suppl): S233-S255. doi: 10.1111/roiw.12044.

11. Główny Urząd Statystyczny: Rocznik Demograficzny 2014. GUS, Warszawa 2015.

12. Sobotka T, Skirbekk V, Philipov D. Economic Recession and Fertility in the Developed World. Popul Develop Review. 2011; 37(2): 267-306.

13. Eurostat 2016. http://ec.europa.eu/eurostat (access: 2016.08.27).

14. Kotowska I. (red.). Niska dzietność w Polsce w kontekście percepcji Polaków. Diagnoza Społeczna 2013. Ministerstwo Pracy i Polityki Społecznej, Warszawa 2014

15. Hoem J, Mureşan C, Hărăguş M. Recent features of cohabitational and marital fertility in Romania. Population. 2013; 68(4): 667-695.

16. Wojciechowska M, Krauss H, Bogdański P, Mikrut K, Chęcińska Z, Szulińska M, et al. The assessment of selected factors influencing intent to get pregnant in the Greater Poland Region. Ann Agric Environ Med. 2014; $21(2): 435-439$.
17. Matysiak A. Posiadanie własnego mieszkania a rodzicielstwo w Polsce. Stud Demogr. 2011; 159(1): 37-55.

18. Currie J, Schwandt H. Short- and long-term effects of unemployment on fertility. Proc Natl Acad Sci USA. 2014; 111(41): 14734-14739.

19. Kulu H. Why Do fertility levels vary between urban and rural areas? Region Studies. 2013; 47(6): 895-912.

20. Europejska Fundacja na rzecz Poprawy Warunków Życia i Pracy: Jakość życia na obszarach miejskich i wiejskich Europy. Eurofound, Luksemburg 2014.

21. Farmer J, Munoz S, Threlkeld G. Theory in rural health. Aust J Rural Health. 2012; 20(4): 185-189.

22. Kulu H. Fertility of internal migrants: comparison between Austria and Poland. Popul Space Place. 2006; 12(3): 147-170.

23. Brzozowska Z. Przestrzenne zróżnicowanie urodzeń pozamałżeńskich w Polsce w latach 2002-2010. Stud Demogr. 2011; 160(2): 59-83.

24. Podogrodzka M. Przestrzenne zróżnicowanie płodności w Polsce. Stud Demogr. 2011; 160(2): 85-106.

25. Baranowska-Rataj A. Decomposition of trends in non-marital childbearing in Poland. Population-E. 2014; 69(2): 239-253.

26. Szukalski P. Regionalne zróżnicowanie kalendarza płodności we współczesnej Polsce. Probl Polit Społ. 2014; 27(4): 55-73.

27. Gałka J, Kurek S, Wójtowicz M. Differentiation of reproductive behaviour of the population of the Kraków Metropolitan Area in the light of survey research. Bull Geogr Soc Econ Series. 2016; 31: 45-57.

28. Potârcă G, Mills M, Lesnard L. Family formation trajectories in Romania, the Russian Federation and France: towards the second demographic transition? Eur J Popul. 2013; 29(1): 69-101.

29. Food and Agriculture Organization. FAO Statistical Yearbook 2014. Europe and Central Asia food and agriculture. FAO, Budapest 2014.

30. Valkonen T, Blomgren J, Kauppinen T, Martikainen P, Mäenpää E. The effects of regional socioeconomic and cultural characteristics on the spatial patterns of the Second Demographic Transition in Finland. Demogr Research. 2008; 19(61): 2043-2056.

31. De Beer J, Deerenberg I. An explanatory model for projecting regional fertility differences in the Netherlands. Popul Res Policy Rev. 2007; 26: 511-528.

32. Goldstein J, Klüsener S. Spatial analysis of the causes of fertility decline in Prussia. Popul Develop Review. 2014; 40(3): 497-525.

33. Dribe M,Breschi M,Gagnon A,Gauvreau D,Hanson H,Maloney T, et al. Socio-economic status and fertility decline: insights from historical transitions in Europe and North America. Popul Stud (Camb). 2017; 71(1): 3-21.

34. Główny Urząd Statystyczny: Prognoza ludności na lata 2014-2050. GUS, Warszawa 2014.

35. Lewandowski P, Iga M (red.). Zatrudnienie w Polsce 2013. Praca w dobie przemian strukturalnych. CRZL, Warszawa 2014.

36. Colleran H. Farming in transition: land and property inheritance in a rural Polish population. Soc Biol Hum Aff. 2014; 78(1\&2): 7-19.

37. Colleran H, Jasienska G, Nenko I, Galbarczyk A, Mace R. Fertility decline and the changing dynamics of wealth, status and inequality. Proc R Soc. 2015; 282(1806): 20150287. doi: 10.1098/rspb.2015.0287.

38. Michalska S. Tradycyjne i nowe role wiejskich kobiet. Wieś Roln. 2013; 159(2): 124-139.

39. Czapiński J, Panek T. (red.). Warunki i jakość życia Polaków. Diagnoza społeczna 2015. Rada Monitoringu Społecznego, Warszawa 2015.

40. Podogrodzka M. Przestrzenne zróżnicowanie poziomu oraz dynamiki zawierania małżeństw w Polsce w latach 1999-2011. Przegl Geogr. 2013; 85(2): 243-269.

41. Simon C. Do higher rents discourage fertility? Evidence from U.S. cities, 1940-2000. Region Sci Urban Econ. 2009; 39: 33-42.

42. Kovac J, Addai J, Smith R, Coward R, Lamb D, Lipshultz L. The effects of advanced paternal age on fertility. Asian J Androl. 2013; 15: 723-728.

43. Wdowiak A, Wdowiak A, Moroz E, Bojar I. Comparison of selected sperm parameters between 6,278 males in Poland and Ukraine. Ann Agric Environ Med. 2016; 23(1): 174-181.

44. Zgliczyński W. Wynagrodzenia w Polsce. BAS; 22(159): 1-4.

45. Kulu H, Washbrook E. Residential context, migration and fertility in a modern urban society. Adv Life Course Res. 2014; 21: 168-182.

46. Szukalski P. Demografia współczesnego dzieciństwa. Polit Społ. 2009; 9: $2-5$. 